\title{
ETHNIC CONFLICT IN NAGORNO-KARABAKH
}

Melita Kuburas

University of Toronto

\begin{abstract}
Twenty years since the conflict between Azerbaijan and Armenia over the Nagorno-Karabakh region first began, 610,000 people are still internally displaced in Azerbaijan, living in poverty and in wretched housing conditions. The causes of violence in the ongoing ethnic conflict between Armenia and Azerbaijan, which began in the late 1980s and has since resulted in 30,000 deaths, can mainly be analyzed using a constructivist framework. However, elements of a primordialist approach to national identity were also used by mobilizers to trigger political and social uprisings. This paper presupposes that the constructivist theories on identity formation and territorial claims offer a better explanation as to why the war over Nagorno-Karabakh broke out in the 1990s, and why, in 2010, the two parties are no closer to a resolution and the Nagorno-Karabakh region remains in limbo.
\end{abstract}




\section{Introduction}

In central Baku, an abandoned, decrepit, Soviet-era factory today serves as home to about 20 Azerbaijani families who were displaced in the early 1990s from Nagorno-Karabakh. A series of photos taken by a reporter in March of 2010 show makeshift apartments divided with leaning slabs of cardboard and plaster. Young boys play on the remains of an old vehicle, later moving to the slightly more welcoming indoors, where colourful curtains and carpets are carefully arranged by their mothers - a desperate attempt to make the place look more like home (Atilay 2010).

The families featured in the photo essay by a Radio Free Europe correspondent represent just a handful of about 610,000 Azerbaijani refugees displaced by the conflict between their country and neighbouring Armenia over the Nagorno-Karabakh region. Rightful ownership of the mountainous area in south-western Azerbaijan has been the subject of debate between Armenians and Azerbaijani for centuries. The dispute came to a head in the late 1980s when Armenians requested to have the region annexed to the republic of Armenia, and used military force to occupy the territory when the call for sovereignty was denied. The dismal living situation for internally displaced persons (IDPs) 16 years after the 1994 ceasefire represents the severity of Armenian military operations that cleansed the mountainous region of ethnic Azerbaijani residents. However, the refusal by Azerbaijan's government to accommodate IDPs into society indicates there is no imminent resolution or agreement between the states over the Nagorno-Karabakh territory.

\section{Argument}

In an examination of the events leading up to the ethnic violence in Nagorno-Karabakh that started in the late 1980s and which has since resulted in 30,000 deaths, this paper argues that the leading causes of war fall under the umbrella of perception and opportunity - the role of key players and institutions since 1989. This includes Russian military policies in the 1990s, and that the actions of political elites in Armenia and Azerbaijan's domestic governments.

At the epicentre of the conflict is the concept of territory, which both parties view as having an intrinsic worth and value to their respective groups. The primordial claim to territorial ownership establishes historic legitimacy based on the ancestral tenure of a given ethnic group, and gives more weight to a land claim if an ethnic group is autochthonous to the land (Astourian 1994, 73). In contrast, the constructivist approach recognizes the unreliability of this argument for ownership (because identity is a fluid concept), and it instead uses the maps and border definitions of centuries past as evidence or affirmation of territorial claims. Central to this conflict is the influence of the Soviet Union and the nation-building policies of the $20^{\text {th }}$ century, which contributed to political and economic grievances among irredentist minorities in the Caucasus.

Primordial views of nationality and territory do provide an important context for the region, as they were used in the Soviet period in an effort to affect popular consciousness. Joseph Stalin and other Bolshevik leaders believed that hatred between nations was fuelled by capitalism and communism would lead to cooperation between different nationalities (Tillett 1969, 22). However, Stalin later made telling allusions to the weaknesses of the "great friendship," which was a belief that communism would stifle the nationalist feeling and chauvinism among different Soviet peoples. For example, in a speech in Tbilisi in 1921 he noted that "among the workers and peasants nationalism has developed, a feeling of distrust for their comrades of other nationalities has intensified" (Tillett 1969, 25). Later, it was because of Mikhail Gorbachev's glasnost reforms that these grievances were aired in the form of protests, referendums and calls for secession, igniting the bloody and irresolute war in Nagorno-Karabakh.

Primordial attachments to the Nagorno-Karabakh territory are often cited as a cause of this war by people on the ground - the victims and the perpetrators of violence. Yet this notion of hatreds resulting from ancient cultural myths is often dismissed by scholars as a simplistic analysis of identity formation and causes of conflict. This is correct, as in the Nagorno-Karabakh case. It was the border treaties and mapping of nations throughout the $20^{\text {th }}$ century that were used to construct territorial claims and cause 
grievances and perceived institutional inequalities. While primordialist claims played an important role in the shifting political tides at the moment, including the development of popular front and nationalist movements in the region, these hostile views held within Armenia and Azerbaijan were manipulated by political elites who, because of the instability of both states at the time of the breakup of the Soviet Union, were able to mobilize an armed rebellion in the early 1990s. A more accurate view of the ethnic strife at the time then would be to consider the political changes within the two states in question, as well as the international realm, and the actions of the military and local elites who manipulated events to make their case for ownership of Nagorno-Karabakh.

\section{Theory}

This paper presupposes that the constructivist theory on identity formation, which explains national histories and identities as fluid, evolving, and formed over time (Suny 2001, 865), offers a better explanation as to why the war over Nagorno-Karabakh broke out in the 1990s, and why, almost 20 years later, the two parties are no closer to a resolution and the Nagorno-Karabakh region remains in limbo.

A primordialist land claim views the Nagorno-Karabakh territory as being fixed and bound to a particular ethnic identity; as the cradle of a group's linguistic, cultural or religious origins. Since both Azerbaijanis and Armenians living in the region do make a claim on the territory based on this type of narrative, the conflict can be seen as the result of ancient grievances between the two groups - as embedded hatreds that are "permanent and ineradicable" (Laitin and Suny 1999, 153). However, the primordial approach ignores the periods of relative peace and stability between the two groups, and it does not account for other triggering factors, such as Soviet nationalization policies, elite mobilizers and opportune military strategies, all of which contributed to the conflict as well.

While ethnic conflict is statistically a rare cause of war, between 1989 and 2007, the wars in the post-Soviet Union and the former Yugoslavia accounted for 30 per cent of all internal wars around the world (Zurcher 2007, 219). Soviet policies on nation-building and indigenization contributed to feelings of deprivation among Armenian minorities living in Nagorno-Karabakh. In Roger D. Petersen's theoretical approach to ethnic conflict, an emotion-based framework explains the emotive sequence that turns resentments, fears and group consciousness into violence or support for institutional discrimination (Petersen 2002, 23). Even though his is a constructivist approach, one of the components is the primordial view of "ancient hatreds," or how targeted violence against a particular group can be repeated throughout history once there is an opportunity that results from the structural collapse of a governing centre (Petersen 2002, 25). This theory applies to the argument in this paper where the ethnic conflict in Nagorno-Karabakh is analyzed using mainly a constructivist approach, while maintaining that certain primordial elements are still instrumental to the causes. Emotion-based theory takes into consideration the role of elites in framing the situation in a particular way to affect national consciousness (Petersen 2002, 34 ), which can be applied to the case study of Nagorno-Karabakh examined below.

\section{Territory and national identity - a primordial outline}

Individuals who belong to the same ethnic group may share traits such as language, race or religion, as well as a belief in a common destiny or heritage - but all these are often encompassed by, or associated with, a given territory (Duffy Toft 2003, 19). Azerbaijani and Armenian historians have written extensively about their collective cultural memory and myths, arguing that their respective ancestors originated from Nagorno-Karabakh. The Soviets encouraged the writing of histories of the non-Russian peoples by encouraging primordialist national myths, for instance the History of the Kazakh S.S.R., which was devoted to the Kazakh military traditions, emphasized struggles for independence in tsarist times and praised Kazakh heroes such as Sultan Kenesary Kasymov (Tillett 1969, 73-73). Through such direct involvement in the writing of historical narratives, "the themes of the elder brother and the friendship of peoples were popularized in a growing number of publications on the cultural contacts of Russians and non-Russians" (Tillett 1969, 252). These myths contribute to the primordial construction of national 
identity, which supports a group's ownership claim to a "homeland" based on the length of time their ancestors have resided there. If there are conflicting claims by two ethnic groups to the same land, the disagreement is often viewed as the result of ancient, religious, or traditional hatreds. After the 1950s, this type of behaviour was portrayed by Stalin as common to the non-Russian peoples. After the Second World War, the Russians themselves were considered by Stalin to be of a superior culture that needed to influence and defuse the growing nationalism of the non-Russian peoples (Tillett 1969, 382).

\section{Primordial cultural myths and territorial claims}

Armenians believe that Caucasian Albania (which ruled the Caucasus until the $2^{\text {nd }}$ century BC when parts of it were conquered by Armenia) was influenced by bishop Grigoris, of Armenia, who is buried in the oldest church of Karabakh, in the Hadrut region (Walker 1996, 89). In the eighth century, Armenia was recognized as an administrative province by the Arabs, outgrowing Albania as a state. This area, known as Artsakh, is viewed by Armenians as "the cradle of Armenian identity" (Stern 2003). It is where the first Armenian school was opened, in present-day Martuni District of Nagorno-Karabakh. Earlier, in 301, Armenian scholars believe that Armenian preacher and military leader Mesrop Mashtots had created or revived the Armenian alphabet (Stern 2003). This narrative therefore contributes to the Armenians' primordial argument for their Nagorno-Karabakh land claim, which insists that Armenian Christian and linguistic origins are rooted in the Nagorno-Karabakh region. As the centuries passed and the Caucasus were handed over and traded by international powers with expansionist ambitions, Nagorno-Karabakh remained the commune of Armenian culture preserved by their ancestors the Meliks.

The development of Armenian political nationalism in the nineteenth century, which continued in Armenia after Sovietization, became associated not just with the movement for Armenian independence but also with the grievance over Nagorno-Karabakh. The Armenian National Movement, whose roots can be traced back to young activist groups that emerged in Yerevan University in the mid-1950s, is also linked to the Karabakh Committee whose concern was the "lack of cultural freedom and the obstacles to their interacting with their kin in Armenia proper" (Hunter 2006, 29). In the late 1980s the Armenian nationalist movement began to develop its agenda with respect to its external relations. Some members of the new leadership began to argue that irredentist claims might negatively impact its relations with Turkey, a country that it needed as an ally if it was to stop relying on Russia for security (Hunter 2006, 30).

Armenians have what scholar Ronald Grigor Suny refers to as an "unusually strong primordial identity" that shapes their nationalist rhetoric and expression. Armenians emphasize that their collective identity is based on the shared "blood, territory, language and history" of a people who were the original inhabitants of the South Caucasus region. Suny suggests that the essentialist approach to primordial identity, or viewing identity as something that is "fixed, singular, internally harmonious and distinct from others at its boundaries" is comforting to nations. It "cannot be reduced to a mistake, self-deception, or false consciousness" (Suny 2001, 892).

Armenian scholars who favoured the primordialist view argued that, the Azerbaijani national identity is solely a product of Soviet ethno-national construction, hence delegitimizing the Azerbaijani claims to Nagorno-Karabakh. However, the Azerbaijanis reject the suggestion that their nation is merely a by-product of the Soviet struggle to keep together a multi-national state. They have identified with clans, tribes and Muslim peoples who have also lived in the area for centuries, hence creating their own primordial claim.

According to the Azerbaijani narrative, the Meliks are descendants of the Jalalid, with no Armenian ancestry. They see the Karabakh area as "one of the historical hearths of the Turkic culture of Azerbaijan" (Alijarly 1996, 129). From the $4^{\text {th }}$ century onwards, Karabakh was aligned with kingdoms to the east - in present-day Azerbaijan (Goldenberg 1994, 157). They refer to early Arab authors who drew maps of Nagorno-Karabakh as belonging to Caucasian Albania, "the most ancient state of Northern Azerbaijan" (Stern) as far back as the year 731 (Alijarly 1996, 113). Azerbaijanis also believe that some of their authors, poets, artists and scientists were from the region and are buried in Nagorno-Karabakh. 
This argument over land entitlement that takes its cues from ancient myths and essentialist national identity formation can be seen as contributing to the tense ethnic conflict in Nagorno-Karabakh. The religious overtones especially paint this as an ecclesiastical dispute, fought over by Christian and Muslim rivals. However, religious framing alone doesn't explain why Armenia and Iran, a Muslim state, have maintained diplomatic relations for a long time. There is the perception of "pan-Turkic" oppression. Some Armenians see Azerbaijani hostility as akin to the assault by the Turks during the First World War, which resulted in the death of more than one million Armenians in 1915. Armenians consider the deaths to be an act of Genocide, which Turkey has vehemently denied. This difference in the nations' opinions contributed to the chaotic violence that ensued during the war (Hunter 2006, 45). Turkey's influence in the region has had an important impact on Nagorno-Karabakh, not least because of interpretations of Azerbaijani language and culture that point to Turkish origins. Turkish influence among the Muslim states of Central Asia and the Caucasus has led to Turkey adopting a decidedly pro-Azerbaijan stand towards the conflict as part of its strategy to maintain influence in the country (Hunter 2006, 45-46).

Both sides believe their stories offer a form of historical legitimacy to the Nagorno-Karabakh land claim. It follows that central to the primordial argument, with respect to the causes of the current war, nationhood, in its full realization, "requires the form and frame of territorial polity" (Brubaker 1996, 55). However, the ancient hatreds argument does not wholly explain why the ethnic violence in this case erupted in 1988. Until then, there were about 724,000 ethnic Azerbaijanis living in Armenia (International Crisis Group 2005) and about 360,000 Armenians in Azerbaijan who emigrated between 1988 and 1993 (The UN Refugee Agency 2004). While the historic suffering of the Armenians cannot be dismissed as an essential factor that helped mobilize nationalist sentiments and fuel ethnic violence, Azerbaijanis and Armenians had coexisted without incidents of violence or pogroms for most of that time. Their unwavering attachment to the territory and propensity towards violence could be explained using the constructivist approach to identity formation, which argues that the ethno-territorial dispute is a result of key events and agreements in history.

\section{Territory - a constructivist outline}

The following section refers to the various treaties and agreements that attempted to resolve the issue of the contested territories, but in turn only provided for more resentments and caused each side to argue that Nagorno-Karabakh should belong to them. At the outset of political instability in the late 1980s, the challenge for both nations, if they wanted to assert themselves in the international realm, was to construct an argument that the enclave should belong to them - an argument that went beyond the ancient historical presence of their people, and incorporated the role of external players in the ownership claims of their territory. In this sense, the constructivist theoretical approach to territorial claims begins to take on a more important role than the previous primordialist claims.

One of the key obstacles to a rational settlement in territorial disputes is what social scientists refer to as the "indivisible issue" - this is precisely the issue with Nagorno-Karabakh where the territory is viewed by both ethnic groups as being an undividable homeland (Duffy Toft 2003, 2). When there are calls for sovereignty by a nation, a contested territory becomes the root of ethnic conflict when "competing claims are not prevented, regulated or managed by political control or institutionalized compromise" (Hughes and Sasse 2002, 4). The rightful, legal and historical ownership of the territory is asserted by both parties in order to support their claim over the lands today.

Azerbaijanis, for instance, will often refer to the Batum Treaty of 1918 between the Ottoman Empire and Armenia which gave the state "only the Erevan and Echmiadzin districts, some 10,000 sq. km" (Stern 2003). This treaty however, was by no means respected, and a bloody ethnic conflict raged in Nakhichevan, Karabakh and Zangezur throughout the year. Turkish troops invaded Nagorno-Karabakh later that year but left soon after, and the British believed that territorial disputes should be presented and resolved at the Peace Conference following the end of the war (Hille 2010, 163). When a British representative negotiated land claims at the end of the war with the Ottoman Turks in 1919, Khorsov Bek Sultanov, a wealthy landlord in Karabakh and member of the Musavat, a nationalist bourgeois party in 
Azerbaijan, was installed as governor of Karabakh - an order that the Armenians found unacceptable because of Sultanov's "pan-Turkic" views (Walker 1996, 99). Azerbaijanis see the settlement that unfolded with the help of the British as recognition that the territory rightfully then belonged, and still belongs, to the republic of Azerbaijan. Armenians, however, see the inclusion, negotiated in 1919 in the Treaty of Sevres and signed by Armenian president Avetis Aharonian and representatives of the Ottoman Empire, as a coercive agreement that took advantage of their "exhausted and dispirited" people (Walker 1996, 100). The dissatisfaction over territorial settlements continued into the period of Soviet rule, and was, in fact, exacerbated by the Soviet political agenda.

In November 1920, the Azerbaijan Revolutionary Committee, a Soviet organization that overthrew the government of the Musavat Party, recognized the disputed regions of Zangezur and Nakhichevan as integral parts of Soviet Armenia and granted Nagorno-Karabakh the right to selfdetermination. This mediation was intended to resolve some of the regional disputes in Transcaucasia and initially helped Bolsheviks take power in Armenia. On July 4, 1921 it was officially decided that Nagorno-Karabakh would be unified with Armenia, but this decision was reversed the following day and Nagorno-Karabakh was instead recognized as part of Azerbaijan with the status of an Autonomous Oblast (Hille 2010, 168). Armenia was satisfied to be able to retain Zangezur, which in 1918 was the location of the ethnic strife between the two groups. But this allocation was implemented not out of concern for Armenia, but out of the Soviets' own political and economic strategy. Lenin wanted to separate Azerbaijan and Turkey, so he assigned the Zangezur southern tip to Armenia. Armenians did not want to be landlocked by Turkey and Azerbaijan, and therefore preferred this connection to Iran. It is important to consider why the Soviets refused to annex the region to Armenia, especially when their claim to the territory technically adheres to the principle of majority rule, and, if we are to accept the argument that their ancestors were the first to settle the territory, the principle of tenure. The decision to assign Nagorno-Karabakh to Azerbaijan therefore was mainly one of strategic economics. The Bolsheviks saw that Azerbaijan, with its larger population and oil resources was, a more important player to appease than Armenia (Hille 2010 169). This serves as an example of how the interests of states can help contribute to antipathy among different ethnic groups and contribute to nationalist feelings that can result from a perception of being collectively wronged or victimized.

Nagorno-Karabakh was declared an autonomous oblast (NKAO) in 1923, but it was to be financially and politically dependent on Baku. It wasn't just this declaration that Armenians in Armenia took issue with - it was also the drawing of the new border, which excluded a north-western part of Karabakh from the oblast and established the Lachin corridor to physically separate the region from Zangezur. The physical construction of the border was meant to provide distance between the Armenian majority in Nagorno-Karabakh, comprising about 90 per cent of the population in NKAO, and the republic of Armenia proper. But a six-mile swath of land, that is the Lachin strip, is not enough to reduce the likelihood of secession and conflict, especially when one ethnic group has a neighbouring "big brother" to look out for it and intervene on its behalf (Zurcher, 2007, 184).

The Soviet management of territorial borders showed the struggle to build and maintain a multinational state. Across the union, societies living within the newly drawn borders were far from homogenous representations of the ethnicities and culture that lived there. Armenians were a minority in Azerbaijan, and as a minority they were concentrated in Nagorno-Karabakh. To have annexed this enclave and made it part of Armenia would have fuelled a political crisis in the region, and set a precedent for minorities living in similar circumstances across the Union. Ultimately, this is exactly what happened in 1987 when Armenians living in Nagorno-Karabakh began to protest asserting that Nagorno-Karabakh should be transferred to Armenia, officially voting for accession a year later. The next section of this paper will explore why minorities felt these grievances, the reasons they felt they could assert their nationalist rights in the Soviet Union, and how the supranational government in Moscow shaped this discourse from 1920s onwards with respect to nation-building policies. 


\section{Soviet nation building and identity construction}

In the Caucasus, claims over territory are made in accordance with group interpretations of national histories (Astourian 1994, 41). After the October Revolution, the Soviets did not want to replicate the geographic divisions as they existed in Tsarist times - they wanted to form national-territorial borders that would consolidate ethnic identity by institutionalizing nationality at the state level (Saroyan 1997). For example, cultural organizations like state publishing houses and ministries of culture were established according to the indigenous national community in a given region, and unions were set up to aid in the development of their national cultures, arts, languages, and architecture (Saroyan 1997, 177). Because the Soviets believed geographical boundaries were supposed to link up with ethnic demographics, a "strong sense developed that each nationality ought to have its own territory" (Laitin and Suny 1999, 148). When this did not occur or was not possible, nations felt anger and resentment that translated into bitterness against those who did, aiding in the construction of nationalist sentiment due to perceived oppression and the unjust superiority of the other.

Before 1905, the Azerbaijanis were known as Caucasian Turks, Tatars, or Muslims, and it was Soviet power in the 1930s that gave them the "Azerbaijani" identity. The Soviets trained local political, economic and cultural elites, stressing a form of genealogical nationalism, which is one of the reasons for the rise of secessionist ethnic conflict and irredentist struggles (Astourian 1994, 69). By depositing local elites in government who would remain loyal to the Soviet leadership, indigenization policies were, in essence, designed to concentrate power in the Moscow centre.

Until the mid-1930s these policies included language preservation intended to fertilize a "blossoming" of the nations and strengthen the consciousness of national identity. It accomplished this in part by guaranteeing that schools would be taught in the local ethnic languages as opposed to Russian. In the 1920s the Soviet centre also for the first time began to promote locals to the Soviet party apparatus (Fowkes 1997). While Stalin abandoned this "localist" approach by the mid-1930s, it was later resuscitated by Nikita Khrushchev during the late 1950s and 1960s, and would eventually help mould local and national identities into political movements. This process strengthened the core ethnic group living within a republic, and it furthered their nationalist claims over the territory that their republic's border covered. Minority groups who were living within these same boundaries saw this as the Soviets giving preferential treatment to the core majority, and hence as diminishing their own claims to the land. There is proof that minorities were subordinated to the titular nations in the republics, and often encouraged to migrate back to their "homeland" under Stalin in the 1940s and again in the 1980s (Suny 2001, 148).

This perceived depravation is a central point of the Armenian grievance with respect to NagornoKarabakh. Because Karabakh was a part of the Azerbaijan republic, Armenians argue that education was severely underfunded; that there were no Armenian-language textbooks or TV broadcasts; and no subsidies for Armenian cultural development (Saroyan 1997, 178). By restricting the use of Armenian language in education, by not providing health clinics in Armenian villages and leaving historical monuments to rot away, Armenians claimed that the Azerbaijanis tried to destroy Armenian roots and culture, which became the core argument for their claim to secession in the late 1980s. The other argument made by Armenians living in Nagorno-Karabakh was that of economic deprivation - they asserted that the region was disadvantaged and its agriculture industry neglected by the republican centre in Baku.

However the claim that Nagorno-Karabakh suffered regional economic deprivation was likely exaggerated by the Armenians. Karabakh was a "backward region" when compared to urban centres such as Erevan and Baku, but "according to most economic indicators, it was more prosperous than other regions in Azerbaijan" (Zurcher 2007, 221). The economic argument also lost credibility after Henrik Pogosian, first Secretary of the Regional Committee in Karabakh and a supporter of the Armenians, delivered a speech in 1988 that instead portrayed Nagorno-Karabakh as an economically productive region that was, in fact, financially supported by the Azerbaijan Republic at large (Zurcher 2007, 160). This speech also came just after ethnic violence broke out in Sumgait, after which Pogosian demanded the 
separation of Karabakh from Azerbaijan. Perhaps, what is more important than accurately assessing the level of economic prosperity of Nagorno-Karabakh at the time is the underlying sentiment of both versions of the story - that the time had come when the two groups could no longer live together.

While the Soviet nationality policy ultimately aimed for a sblizhenie, or coming together of the new socialist people, by "embedding ethnicity into politics," (Suny 2001, 149), it was a goal that failed. This is evidenced by the nationalist and popular front movements that bulldozed out of the 1980s and helped establish sovereign, nationalist states. One of the outcomes of the korenizatsiia or indigenization process that had the greatest impact with respect to mobilizing ethnic conflict was the formation of local elites. By favouring ethnic Azerbaijanis for political and economic promotions over Russian or Armenian candidates, the Soviets enabled Azerbaijani elites to dominate the political sphere. Minorities in the republics saw this as political disenfranchisement (Saroyan 1997, 178). Whether or not there is evidence to support the view that Armenians were marginalized by these policies, it cannot be denied that the role of the nomenklatura in the mobilization of ethnic conflict was a central one. This became most apparent at the start of the conflict in the late 1980s when incumbent and challenging elites, using the institutional power officially afforded to them but never before exercised in the Soviet Union, called for the annexation of Nagorno-Karabakh to Armenia. This was only possible because of the change in Soviet leadership, as Gorbachev's perestroika reforms allowed open protest and hence had a direct impact on the war in Nagorno-Karabakh. Such grievances can be seen through the framework of Petersen's emotionbased theory on ethnic conflict, where resentments based on status relations are turned into rage and contribute to the violence in the region.

In February 1988, the Nagorno-Karabakh Supreme Soviet legislative body appealed to the Supreme Soviets of Armenia, Azerbaijan and the USSR to allow NKAO to join the Armenian Soviet Socialist Republic. Two days later, the Azerbaijani SSR rejected it. Because such a clash between Union Republics was without precedent in the USSR, Moscow had to make a quick decision on how to respond to the dispute. In July 1988, the central Soviets decided to maintain the disputed region within Azerbaijan, however as the situation escalated, in January 1989, Moscow established direct governance over Nagorno-Karabakh. Rebellions that led to accusations of a pogrom in Sumgait helped mobilize the Armenian public to support the new nationalist Karabakh Committee, a dissident group of Armenian intellectuals formed in response to Gorbachev's glasnost reforms who concerned themselves with Armenia's future - starting with a campaign to annex Nagorno-Karabakh to Armenia proper (Hunter 29). Official reports suggest that the violence and bigotry went both ways. More than six Azerbaijanis were among the 30 deaths in Sumgait, and Azerbaijanis complained that the Armenians were discriminating against them as a minority within Nagorno-Karabakh, "where government and party bureaucracies were predominantly Armenian" (Altstad 1996, 231).

The violent outburst is likely to have been the culmination of grievances on the part of Armenians in Nagorno-Karabakh for being subordinated to the Azerbaijani nation, or what Jeremy Smith calls "national hierarchisation" - where the core nationalities of titular republics were considered superior to the minorities who also lived within the same borders (Smith 2000). Therefore, while the Soviets perhaps looked forward to one day eroding nationalities and conflicts through modernization and promotion of Marxism, paradoxically, their indigenization policies only enhanced the cohesion of titular nations, and in turn fuelled the inter-ethnic hostilities within the borders that they resided in (Suny 2001, 875). In the Caucasus territorial borders cannot easily be drawn to coincide with cultural or ethnic realities. Hence the "ethno-cultural" model (Brubaker 1996, 56) that the Soviets favoured could not align with the mixed populations of Armenia, Azerbaijan, and Georgia. The Soviets tried, using the best means available to them at the time, but this often resulted in an arbitrary ethno-territorial design. By the 1990s, it had been clear that minorities living in a nationalizing state such as Azerbaijan would not enjoy the perks of national representation and access to administration that the core nations had within the Soviet empire. But the main difference, at that point in history, was that minorities were finally able to voice their concerns, which they were not able to do under earlier Soviet leadership.

In 1988, mass demonstrations in Erevan and Stepanakert, the administrative capital of NagornoKarabakh, were accompanied by an appeal to Moscow to transfer the enclave to Armenia. Gorbachev, 
fearing an uprising in Azerbaijan, did not want to openly side with Armenia and is quoted as saying: "the only exit from the situation is a political one. We could not bring about a decision in Afghanistan and here it is the same" (Fowkes 1997, 159). He placed NKAO under special administration citing Article 78 of the USSR Supreme Soviet constitution, which forbids territorial changes without the agreement of all republics concerned (Altstadt 1997, 231). As a result, both parties were dissatisfied with Moscow. Armenians claimed that the calls for secession were in accordance with the USSR law on the "Procedure for Solving Issues of Secession of a Soviet Republic from the USSR." Article 3 of this law provided autonomous republics within the Soviet Union with the right to determine independently, by referendum, whether they wished to remain within the USSR or secede from it. While many in Azerbaijan had feared Moscow would side with the Armenians because of the accusations that there had been a pogrom, the fact that NKAO remained within the country did not appease the Azerbaijani government, because Baku did retain direct administration of Stepanakert (Altstadt 1997, 232). Therefore, the political institutions of the USSR and the flip-flopping and weakness of the Gorbachev regime contributed to the ethnic grievances in the Caucuses. Some, however, argued that the Soviet interference was even more direct - that Soviet soldiers sold weapons to both sides and fought on both sides during the war, "even after the fall of the Soviet empire" (Altstadt 1997, 232).

\section{Soviet nation building and identity construction}

When political shuffling and military actions contribute to fears and resentments, a solely primordial approach is insufficient for understanding and explaining the conflict and omits several additional key factors that led to the rise in violence in 1988. Azerbaijan and Armenia declared independence in August and September of 1991, respectively. Operation koltso (Ring), launched in 1991 by Azerbaijani forces to disarm Armenian militia failed - they underestimated the resistance of the Armenians troops who continued to mount assaults against civilians in the region. Azerbaijan, like other former Soviet Union states at the time, was inefficient and discombobulated, and could not gather enough troops to fight the attack from within its borders. A weak department of defence and internal security is, in part, to blame, and this was a residual effect of the collapse of the Soviet Union, which "left the successor states without any meaningful institutions that could have claimed the monopoly on violence" (Zurcher 2007, 213). It was also this weakness of the central state that increased Armenian paranoia - they felt that if ethnic violence was directed from Baku, they would not be protected by the Soviets. Therefore, while Azerbaijan was too weak to defuse any growing secessionist movement, Armenians, in turn, felt empowered to pursue it.

Armenian military success and Azerbaijan's failure to preserve its borders can, in part, be attributed to the two very different paths that domestic political elites took in the nascent years of the nations' independence. Armenian president Levon Ter-Peterossian rode the tide of the anti-Communist movement, maintaining close ties with neighbouring Russia. In contrast, Azerbaijan "stumbled from coup to coup until state power reverted to the former Communist party boss, Heidar Aliev" (Laitin and Suny 1999, 154). The fragility of the Azerbaijani state can be attributed to the ethnic conflict raging within the region, but also to the lack of solidarity and of a nationalist movement, the absence of which allowed the communist elites to stay in power long past their prime (Laitin and Suny 1999, 156). This collapse of the centre translated into an opportunity for the mobilization of ethnic conflict, as is outlined in the emotionbased theory of ethnic violence.

In 1992 Armenians attacked the town of Khojaly in Azerbaijan, killing hundreds of Azerbaijani citizens. Within a year, they dominated the region and have had a military presence in Azerbaijan ever since. It was this bloody battle that led to the fall of the inactive communist government and allowed for a nationalist reorientation away from Russia and the Commonwealth of Independent States (CIS), towards Turkey. But this government, led by Ablufaz Elchibey, also proved unable to stop Armenian forces. These circumstances heralded the return of Aliev, a savvy politician and former KGB member who, despite continued losses in Nagorno-Karabakh, was able to maintain power. He beat back a coup in 1994, and, together with the Armenians and Russians, helped arrange a ceasefire in Nagorno-Karabakh (Laitin 
and Suny 1999, 156-157). Aliev understood that his alliance with Russia meant that Azerbaijan would have to rejoin the CIS, but he was also aware of the anti-Russian sentiments in the country, which were a result of the bitter memories of the Russian military attack on Baku in 1990.

From 1992 until mid-1993, the Russians withdrew about 60,000 troops from Azerbaijan, and another 25,000 from Armenia (Baev 1997, 38), however Erevan later negotiated for the retention of Russian troops in the capital and establishing of a formal Russian military base.

Russia wanted to maintain relations with oil-rich Azerbaijan, but Russian president Boris Yeltsin also unabashedly supported Armenian president Ter-Peterossian. Such conflicting foreign policy in the Caucasus, some argue "make it obvious that Russia is not interested in a peaceful solution for NagornoKarabakh - peace will inevitably devalue Russia's military assets" (Baev 1997, 43). Ter-Peterossian benefited from the victories in the Karabakh, for which there was great, nationalist support on the part of the Armenian electorate. While Armenia's own economy was in disarray, especially after the earthquake in 1988, the president benefited from military successes such as the capture of the Lachin strip and the stabilization of the front in 1994. The Nagorno-Karabakh dispute can therefore be seen as contributing to the construction of nationalist sentiment in both of the nations in question. Despite the ceasefire arranged that year, occasional violence does still erupt in the region, for example in March 2008 when a 20-day state of emergency was declared in Armenia and several casualties were reported by both groups (Radio Free Europe 2008).

The Conference on Security and Cooperation in Europe or the OSCE Minsk Group, which includes Russia and the US, has not been able to resolve the dispute. The legal balancing act sets the Armenian right to self-determination against the territorial integrity of Azerbaijan. Agshin Mehdiyev, permanent representative of Azerbaijan to the United Nations, has argued to the security council that the Nagorno-Karabakh region of the state "has been captured and held by Armenia, whether directly by its own forces or indirectly by forces forming part of the Nagorny Karabakh Republic" (Compilation on the UN Documents 2008, 156). Supporting the argument that Armenians have undertaken an illegal occupation is the International Covenant on Civil and Political Rights (ICCPR) assertion that there is no provision that statehood must be granted to all the peoples within a particular territory. This was outlined in a case on the legal status of Gagauzes in Moldova. According to the ICCPR there is no generally accepted view that the right to self-determination should be applied to any given state. This means there is no hard, legal support for the Armenians' declaration of sovereignty (Stern 2003). Not even Armenia has recognized Nagorno-Karabakh as a state, as that would jeopardize its role as a supposed mediator in the dispute between the politicians in Nagorno-Karabakh and Azerbaijan. Armenian officials continue to deny that their state has meddled in Azerbaijan's internal affairs. In order to better align with international law, the request by Nagorno-Karabakh for annexation with Armenia was dropped in favour of the call for self-determination.

\section{Conclusion}

The Commission on Security and Cooperation in Europe (CSCE) and Russia have throughout the past two decades disagreed on the best way to mediate the situation in Nagorno-Karabakh. The CSCE wanted to upgrade from a mediating role to having a peacekeeping force, while the Russians thought Russia or the CIS should have a military presence. Armenians, who are suspicious of the international community, believe Karabakh has since moved from being a local conflict in the Caucasus to an international game of power politics because of the presence of Caspian oil (Stern 2003). A poll conducted by the Armenian Academy of Sciences found that an overwhelming majority would prefer a Russian peacekeeping force. Meanwhile, Armenian forces continue to occupy about 20 per cent of Azerbaijan's territory - not just Nagorno-Karabakh, but also much of the south-western region of the country. Armenians believe that Nagorno-Karabakh has already honoured its part of the compromise by renouncing its claim to be conjoined with Armenia, and instead asking for independence. They argue that Nagorno-Karabakh's sovereignty does not depend on international recognition, because Nagorno-Karabakh has a territory, a homogenous, unified population, as well as an elected, organized and functioning authoritative body 
(Stern 2003). The government of Azerbaijan, however, continues to appeal to the United Nations Security Council on the grounds that there has been a violation of international treaties and UN Human Rights conventions. To date, the conflict remains unresolved and despite the fact that the war has resulted in extremely high political and economic costs for both states, neither is willing to concede the territory to the other.

As this paper has argued, the extent to which the ethnic conflict is embedded in NagornoKarabakh is, in part, due to the relationship that both groups have with the territory - they argue it is the cradle of their distinctive religious, cultural and linguistic identities. Both the Armenians and Azerbaijani have constructed primordial arguments around their ancestors' historic tenure in the region. Some see this as bolstering the legitimacy of the Armenian claim to the territory, especially since it suggests the resilience of their cultural or ethnic identity. Although primordial arguments alone could not explain what caused the violence in the late 1980s in this region, it was an important element in the construction of nationalist sentiment needed to mobilize it. Politicians made their territorial claims using the various treaties that divided lands in the Caucasus, and when combined with resentments among nations cultivated by the Soviet indigenization policies, this proves that the constructivist theoretical approach to the formation of nationalist sentiment better explains the leading causes of the war and violence in Nagorno-Karabakh. But what is unique to the region is that certain primordial aspects played a role as well, specifically with the people on the ground who came to resent their neighbours because of perceived injustices committed against them.

In the mid-1960s, Armenians complained to Soviet leader Nikita Khrushchev that "not a single road" had been built and that nothing was done to develop agriculture in Nagorno-Karabakh Autonomous Oblast (Fowkes 1997, 137). They also complained of a "retrograde nationalism" that subordinated their national identity to that of the majority within Azerbaijan. The Soviet drawing of ethno-territorial borders and the use of them for the pursuit of indigenization policies, such as the seeding of local elites in government, exacerbated national ambitions of the titular nations living within heterogeneous republics. But it was impossible to construct homogenous national communities in mixed settlements (Brubaker 1996, 55) and this resulted in the stirring of ethno-nationalist sentiments, which aggravated the conflict in Nagorno-Karabakh. This, in part, is what led to the build-up of grievances and the uprising of minorities in the Caucuses, specifically the Armenians in Nagorno-Karabakh. Meanwhile, Gorbachev's glasnost policies allowed for these grievances to be aired through the form of public protest, which, in NagornoKarabakh, ignited mass violence because of tensions that had been building over the decades.

However, the rebellions and violent clashes may not have exploded into a full-scale war had it not been for mobilizing elites in Azerbaijan and Armenia who commanded the armed forces. They implemented military strategies that simultaneously took advantage of Azerbaijan's political instability and Armenia's nationalist ambitions.

Ethnic groups engaged in conflict often spew hateful and derogatory words against one another, and this makes their dispute appear as if it is rooted in primitive grievances that have been brewing for centuries between people who must, but refuse to, share a given territory. However, this alone does not explain why ethnic wars occur at the time that they do.

\section{REFERENCES}

Alijarly, S. 1996. "The Republic of Azerbaijan: Notes on the State Borders in the Past and the Present." In Transcaucasian Boundaries, edited by J.F.R.Wright, S. Goldenberg, and R. Schofield, 113-33. London, UK: UCL Press.

Altstadt, A. 1996. "Ethnic Conflict in Nagorno-Karabagh." In Ethnic Conflict in the Post-Soviet World: Case Studies and Analysis, edited by Drobizhova L., et. al., 227-54. Armonk, New York: M.E. Sharpe.

"Armenia/Azerbaijan: Deadly Fighting Erupts in Nagorno-Karabakh." 2008. Radio Free Europe (March 4). Accessed on April 10, 2010. http://www.rferl.org/content/article/1079580.html 
Astourian, S. H. 1994. "In Search of their Forefathers: National Identity and the Historiography and Politic of Armenian and Azerbaijani Ethnogeneses." In Nationalism and History: The Politics of Nation Building in Post-Soviet Armenia, Azerbaijan and Georgia, edited by D. V. Schwartz and R. Panossian, R. University of Toronto: Centre for Russian and East European Studies.

Atilay, A. 2010. RFE/RL Azerbaijani Service correspondent Photo gallery. (March). Accessed April 10, 2010. http://www.rferl.org/photogallery/3710.html

Baev, P. 1997. Russia's Policies in the Caucasus, The Royal Institute of International Affairs, Russia and Eurasia Programme. London, UK: Chatham House.

Brubaker, R. 1996. Nationalism Reframed: Nationhood and the National Question in New Europe. New York: Cambridge University Press.

"Compilation on the UN Documents on the Armenia-Azerbaijan Nagorny Karabakh Conflict." 2009. General Assembly Security Council. Sixty third session, Letter dated December 2008, from the parliament representative of Azerbaijan, 156.

Duffy Toft, M. 2003. The Geography of Ethnic Violence. New Jersey: Princeton University Press.

Fowkes, B. 1997. The Disintegration of the Soviet Union - A Study in the Rise and Triumph of Nationalism. New York: St. Martin's Press.

Goldenberg, S. 1994. Pride of Small Nations. New Jersey, USA: Zed Books Ltd.

Hille, Charlotte. 2010. State Building and Conflict Resolution in the Caucasus. Leiden, The Netherlands: Brill.

Hughes, J. and Sasse, G. 2002. Ethnicity and Territory in the Former Soviet Union. London, UK: Frank Cass Publishers.

Hunter, Shireen. 1994. The Transcaucasus in Transition. Washington, DC: The Center for Strategic \& International Studies.

Laitin, D. and R. G. Suny. 1999. “Armenia and Azerbaijan: Thinking a Way Out of Karabakh.” Middle East Policy 7 (1): 145-76.

"Nagorno Karabakh: Viewing the Conflict From the Ground". 2005. International Crisis Group, Europe Report No. 166, (September 14).

Petersen, Roger D. 2002. Understanding Ethnic Violence. Cambridge, UK: Cambridge University Press.

Saroyan, M. 1997. Minorities, Mullahs and Modernity: Reshaping Community in the Former Soviet Union, Edited by E. Walker. Berkley: Regents of the University of California.

"Some 65,000 Refugees from Azerbaijan Gain Refugee Citizenship." 2004. The UN Refugee Agency. (February 6). Accessed on April 10, 2010. http://www.unhcr.org/40239bba4.html

Smith, Jeremy. 2000. "National Hierarchisation and Soviet Nationality Policy from Lenin to Putin." Paper presented at the VI ICCEES World Congress, Tampere, Finland, (August 1).

Stern, D. 2003. Moderator, Council of Europe. (March 31-April 2). Accessed on April 10, 2010. http://www.coe.int/t/f/com/dossiers/evenements/2003-04-Jeunesconflit/Nagorno conflict.asp\#P62 3950

Suny, R. G. 2001. "Constructing Primordialism: Old Histories for New Nations." The Journal of Modern History, 73 (4): 862-96.

Tillett, Lowell. 1969. The Great Friendship. Durham, N.C.: The University of North Carolina Press.

Walker, C. J. 1996. “The Armenian Presence in Mountainous Karabakh.” In Transcaucasian Boundaries, edited by J.F.R.Wright, S. Goldenberg, and R. Schofield, R., 89-112. London, UK: UCL Press Ltd.

Zurcher, C. 2007. The Post-Soviet Wars. Rebellion Ethnic Conflict and Nationhood in the Caucasus. New York and London: The New York University Press. 